\title{
Determinants and Organization Citizenship Behavioral Outcomes of Employee Motivation: An Empirical Study
}

\author{
Allah Wasaya (Corresponding Author) \\ Lecturer, Department of Management Sciences, \\ COMSATS Institute of Information Technology, Vehari, Pakistan
}

Wajid Hussain

Lecturer, Department of Business Administration, Institute of Southern Punjab Multan, Pakistan

Dr. Zahra Masood Bhutta

Assistant Professor, NUML Multan, Pakistan

Received: April 11, 2018 Accepted: April 27, 2018 Online published: May 6, 2018

doi:10.5296/ijhrs.v8i2.12989ＵRL: https://doi.org/10.5296/ijhrs.v8i2.12989

\begin{abstract}
The purpose of this study is to highlight the role of person-organization fit, person-job fit and organizational culture toward organization citizenship behavior. Further, it analyses how employee motivation acts as a mediator between the relationship of person-organization fit, person-job fit, organizational culture and organization citizenship behavior.

For analysis data was collected through a questionnaire based on adopted scales and the sample consisted of 350 employees of $3 \mathrm{~S}$ dealers of automobile manufacturers in Multan district, Pakistan. Exploratory factor analysis and confirmatory factor analysis were conducted to provide statistical evidence for hypotheses. Person-organization fit, person-job fit and organizational culture were found significant in predicting organization citizenship behavior directly and through mediation. Further research should attempt to replicate the findings in other samples. In addition, researcher should investigate other significant variables affecting organization citizenship behavior. Implications of these findings suggest
\end{abstract}


that for management development purpose, people should attempt to improve organization citizenship behavior to create person organization fit as well as organization culture and person job fit. This investigation contributes to the literature by identifying specific organization citizenship behavior rather than macro measures of organization citizenship behavior that are associated with different styles of fits and culture.

Keywords: person-organization fit, person-job fit, organizational culture, organization citizenship behavior, employee motivation, developing country

\section{Introduction}

\subsection{Background of the Study}

Traditionally, the match assessment between job requirements and candidates' qualifications in terms of their abilities, skills and knowledge has been focused in employee's selection research (Sekiguchi \& Huber, 2011). However, with the passage of time, researchers became more interested in the employees' selection potential benefits, which are based on the organizational goals and culture fit (Elfenbein \& O'Reilly, 2007; Brown et al., 1991). Fit of candidate of job includes "person organization (P-O) fit" and "person-f (P-J) fit". P-O fit is referred as the subjective beliefs of employees about how well the culture of the organization match with their personal values (Kristof, 1996; Cable \& Parsons, 2001; Cable \& DeRue, 2002). Practitioners and researchers contend in their study that the key to maintain the committed and flexible work force is P-O fit and it is considered necessary for tight labor market and competitive environment of business (Kristof, 1996; Bowen et al., 1991). Similarly, the considerable evidence amount clarifies, that there are many positive outcomes, which are higher levels of satisfaction of job (Edwards, 1991; Sekiguchi, 2004), higher commitment of organization, attendance, performance, and higher motivation in high level of P-J fit (Sekiguchi, 2004; Edwards, 1991).

The behavioral variable and an important outcome of the individual is organizational citizenship behavior (OCB) and it promotes the organizational effectiveness (Organ, 1988; LePine et al., 2002). Literature on the organization argues that there is a likely impact of P-O fit on OCB through the satisfaction of job (Dyne et al., 1994). Podsakoff et al., (1990) and Netemeyer et al., (1997) noted that there can exist some other factors of mediation besides the satisfaction of job. OC is one of the variables that have been underlined or taken as a potential mediating variable of this relationship by the researchers (Menguc, 2000; Mackenzie et al., 1997). Psychological empowerment (PE) is posited as having a positive or significant impact on OCB (Kim et al., 2013). Moreover, it is suggested that there is a need to have freedom of workplace to display OCB for the employees through empowerment (Harris et al., 2009). It is recommended in the research study of that the empowered workers engaged in OCB perceived a social exchange relationship of high quality with managers. It is also stated that management is considered trustworthy by the empowered employees (Kim et al., 2013).

Aggregated over persons and time, the importance of the organizational citizenship behaviors (OCB) has been increased due to its ability of facilitating the goal accomplishment of the 
organization and enhancing the performance of the organization (Allen \& Rush, 1998). Similarly, empirical research shows that function of OCB is to benefit the organizations in several ways, revenue, customer complaints, sales performance, quantity and quality of the service/product, and customer satisfaction (Podsakoff, Blume, Whiting, \& Podsakoff, 2009; Koys, 2001; Walz \& Niehoff, 1996; MacKenzie, Podsakoff, \& Ahearne, 1998; Podsakoff \& MacKenzie, 1997; \& Karambayya, 1990). Certain ways have been defined by King (2016), by which organizational performance gets effect from OCB. Managerial and coworker productivity may be enhanced by OCB. The ability of the organization to adapt to the changes of the environment is also improved by OCB. To conclude, creation of social capital leads towards the organizational effectiveness through OCB. Organizational culture has an important role in the accepting of the organizational behavior $(\mathrm{OB})$. The word incorporates its foundation from the community anthropology defined by Tylor (1874) like, complex intact which includes awareness, attitude, skill, ethics, regulation, tradition and any other capabilities and behavior acquired by man as a member of society.

Organizational culture has an effective persuade on employees, behavior and attitudes. Organizational culture involves values and norms that recommend how workers should behave in any given organization (Martins, O and Martins, N 2009).

According to Rashid et al. (2004), organizational culture is efficient in establishing worker's attitude towards the changes and policy being adopted by them, he further advocates the position by describing that each organizations has its own height of receiving and culture acts as an significant notion in adopting this change.

\subsection{Research Questions}

The current study tries to answer the following questions.

1. What are the factors affecting organization citizenship behavior?

2. What is the mediating impact of employee motivation on the relationship between person-job fit, person-organization fit. organizational culture and organization citizenship behavior?

\section{Literature Review}

\subsection{Person Organization Fit and $O C B$}

The higher Person organization fit may prompt more noteworthy engagement of OCB toward interpersonal connections. In a comparable vein, when representatives see a high fit with their associations, they demonstrate more elevated amount of modification with their occupations and workplace (Newton \& Jimmieson, 2009) and develop a high authoritative distinguishing proof with their associations (Cable \& DeRue, 2002). Person Organization Fit is characterized as the similarity in the middle of individuals and the association in which they work (Kristof, 1996). Laborers who fit well in their association are more prone to experience positive business related results, for example, more noteworthy occupation inclusion (Blau, 1964), better work disposition (O'Reilly, 1986), and Organizational Citizenship Behaviors (OCBs). OCBs are optional practices that representatives participate into advantage the 
association (Organ, 1988; 1997). In this study, authoritative citizenship practices particularly coordinated towards the association will be inspected. Samples incorporate safeguarding the association and going to discretionary business related capacities. The relationship between $\mathrm{P}-\mathrm{O}$ fit and OCB-Os is not so much direct; rather, a few variables are prone to mediate and moderate the relationship. A meta-examination proposes that the variables, among others, are fixed to individual association fit (Kristof-Brown et al., 2005). These variables address individual qualities and execution capacity that could be identified with the event of OCB. Moreover, these forthcoming directing variables, undertaking execution, self-regard, and pleasantness, allude to the level of sufficiency with which laborers finish their occupation related assignments, how decidedly or contrarily they consider themselves, and the degree to which representatives are charming and obliging. In this study, we concentrate on what develops moderate the relationship between individual association fit and authoritative citizenship practices coordinated towards the association. Next to no exploration has analyzed mediators of this relationship. Vilela et al. (2008) suggested that high P-O fit is a forerunner of OCB. Bateman and Organ (1983) proposed that occupation fulfilment, which is a result of high P-O fit, can prompt OCB. While their study proposes an intercession between P-O fit and OCBs, then again, the individuals who feel detached from their associations (that is who have low P-O fit) are prone to react with ill will towards it. The significance of P-O fit has been accentuated in past research; those whose qualities adjust to the way of life of the association are more prone to experience more positive work related results, for example, higher employment contribution (Blau, 1964), more prominent authoritative responsibility (Meglino, Ravlin, \& Adkins, 1984), and better work demeanour (O'Reilly, 1986). Such workers are more inclined to stay in that environment (Vilela et al., 2008). In fact, we hope to duplicate the finding that the more somebody fits with their association, the more probable they are to take part in OCB.

H1: Person Organization fit has effect on organization citizenship behavior.

\subsection{Person Job Fit and $O C B$}

The employees most favourable attitude toward the jobs will result in psychological attachment to their task or organizations and make these highly evolved the employees be more likely to engage in "extra-role" behaviors (Mowday, Porter, \& Steers, 1982). Furthermore, employees may engage in different types of helping behaviors depend on their perceived extent of attachment to their job and organization. These extra helping behaviors would advance the overall organizational efficiency (Podsakoff \& MacKenzie, 1997). P-J fit is characterized as similarity that exists between an individual trait and the employment attributes and is of two sorts: One is Demand-Abilities (D-A) fit while the other is Need-Supply (N-S) fit (Cable \& DeRue, 2002). D-A fit is alluded as coordinating wager workers Knowledge, Skills and Abilities (KSA) with necessities of their occupations, though $\mathrm{N}-\mathrm{S}$ fit can be alluded as the extent to which representative's needs, desires and inclinations are satisfied by the employments they perform and by the prizes connected with that employments (Cable \& DeRue, 2002). These two sections of P-J fit are presently consolidated into a general idea of P-J fit (Cable \& DeRue, 2002; Vogel \& Feldman, 2009). A solid match exists when an individual has right aptitudes and capacities to perform his 
occupation or the employment can satisfy the singular's need.

H2: Person job fit has effect on organization citizenship behavior

Once individuals are not capable for their jobs or unmatched with organizations, their efforts on residents' quality of life will be reduced as well as the support of other employees at work. Both quality of residents living and employees working environment, would suffer. In contrary, employees who perceive the work is potential for satisfying their needs would highly involve in their jobs (Conger \& Kanungo, 1988). So, this study hypothesizes that:

H2a: Employee Motivation has mediating effect on the relationship between Person-Job Fit and OCB.

\subsection{Employee Motivation and $O C B$}

Motivation influences talent to drive an organization's growth (Rousseau, 1990). Employees also display the certain behavior by going yonder the normal requirements of the job. This behavior is named Organizational Citizenship Behaviors (OCB) and it has been originating to meaningfully contribute to organizational growth (Organ, 1997). Is there any connection between motivation on the foundation of job characteristics and OCB? Whether employee motivation in a way that affects OCB within organizations? Researchers have anticipated a model for exploring apparent relationships between OCB and job characteristics, Accordingly, this research aims to pursue answers to questions concerning to the relationship between OCB and job characteristics. The important theoretical construction in this study is that OCB is affected by the intrinsic and extrinsic motivation, which in return it affects their performance. To enlighten the existence of intrinsic and extrinsic motivation-OCB relationship, the Social Exchange Theory (SET) by Blau (1964) is used as a basis. Social exchange theory (SET) described that all human behavior comprises benefit maximization and cost minimization. Based on SET suggest that one-time exchange can moderately turn to long-term relationship of interest (Molm, 1997). So, it can be hypothesized that:

H3: Employee Motivation has effect on organization citizenship behavior (OCB).

\subsection{Person Organization Fit, Person Job Fit and Employee Motivation}

Herzberg's motivation factors and the job characteristics model provide a link between, P-O, P-J fit and employee motivation. When employees feel that their KSAs enable them to meet their job's demands, they begin to perceive their jobs as important and meaningful; such positive feelings are likely to promote their motivation. Past studies indicate that P-O and P-J fit is positively related to employee motivation (Edwards, 1991). In this kind of situation, a relationship between P-O, P-J fit and employee motivation is shown.

Moreover, social cognitive theory helps to draw a connection between P-O fit, P-J fit and employee motivation. The social cognitive theory is rooted in the view of individuals as being proactively engaged in their own development such that they are more actively involved in taking control of their actions. The key to this is that individuals believe that ", what they think, believe, and feel affect how they behave" (Bandura, 1986). In a work setting, self-efficacy refers to an employee's belief in his or her capability to perform certain tasks 


\section{Macrothink}

International Journal of Human Resource Studies

ISSN 2162-3058

2018, Vol. 8, No. 2

success- fully. In this respect, self-efficacy is relevant to the definition of P-O and P-J fit. Employees, who possess appropriate KSAs and have experienced success on specific tasks in the past, are likely to enhance their self- efficacy; such enhanced self-efficacy can make them feel competent in effectively completing future tasks. Hence, self-efficacy arises from the acquisition of required KSAs through experience or performance. Given that "good performance is self-reinforcing" (George \& Jones, 2002), high P-J fit individuals are more likely to generate a positive feeling about their jobs, which in turn, will inspire their motivation and a sense of subsequently, increase their job involvement and job performance (Greguras \& Diefendorff, 2009; Lent et al., 1994) than those low P-J fit individuals. Accordingly, this study anticipates that person job fit impacts on employee motivation, this mechanism is in the following hypothesis:

H4: Person Organization fit has effect on Employee Motivation.

H5: Person job fit has effect on Employee Motivation.

\subsection{Organizational Culture and $O C B$}

OCB is the behavior more and beyond the delineated or clear roles assigned to individual and is important for well-being and endurance of organization (Borman \& Motowidlo, 1993; George \& Bettenhausen, 1990; Katz and Kahn, 1966). Organizational citizenship behavior is a distinctive assess of workplace output beyond usual measures of work performance and can be conceptualized as positive organizational behavior of individuals (Van Dyne et al., 1994). Organizational culture is the fact that has several positive effects on organization obligation and performance a few to name (O'Reilly \& Caldwell, 1985). Managers and workers thus do not behave in a value-free void; they are governed, bounded for and tempered by the organization's culture (Browne et al., 1996). It is this interactive situation which encourages the workers to put extra effort and achieve outside the arranged role for the accomplishment of organization. Organizational culture defines the 'should's' and the 'ought's' of organizational life by specifying behaviors that are deemed significant in the organization, it can be proposed that:

H6: Organizational culture has a positive effect on organizational citizenship behavior $(\mathrm{OCB})$. 


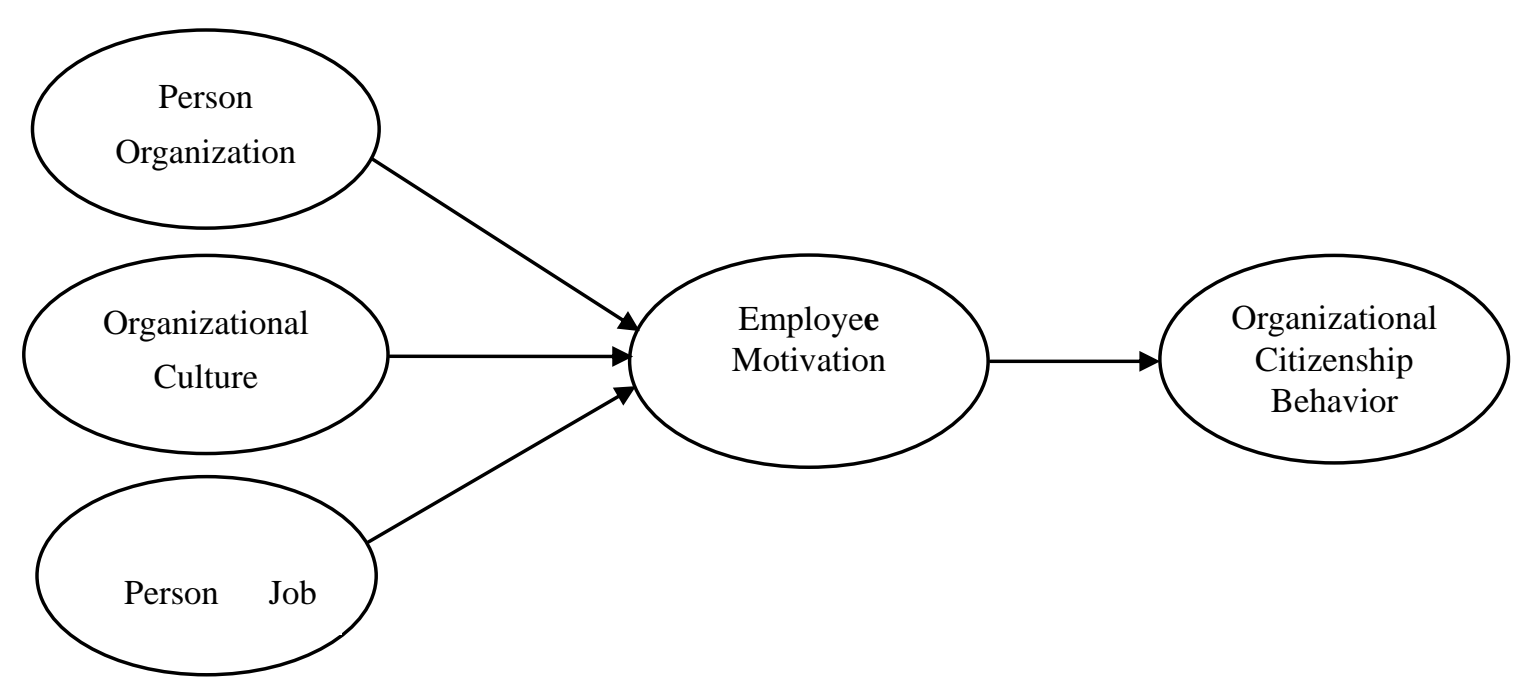

Figure1. Conceptual Framework

\section{Research Methodology}

\subsection{Target Population}

Target population for the study is the employees of service and spare parts staff of $3 \mathrm{~S}$ Dealerships of Automobile manufacturers that is Honda, Suzuki, and Toyota in Multan District.

\subsection{Sample Technique}

Convenient Sampling Technique has been used to collect the data from the respondents in the Multan District due to resources and time shortage. This place is more practical for the members of research and more suitable for field research as this city is market places and workplaces' hub. Several automobile industries are chosen for this research purpose. For the collection of data, "non-probability convenience sampling" is used for obtaining some basic information in quick and inexpensive way. The unit of analysis is Service and Spare part employees.

\subsection{Data Collection Method and Procedure}

Data was collected from the employees by meeting them personally and a sample of 350 employees from 3S (Spare parts, Showroom and Services) dealers of Automobile manufactures. Further, data was collected from the employees during their lunchtime; they were requested to spare some time and to help us to record their responses. They were described about the scope of the research and how their honest responses can be useful in accessing the phenomena with due consideration of confidentiality.

\subsection{Data Processing and Analysis}

For descriptive statistics and to measure reliability of adopted instrument, data will be processed in SPSS and it has also been used for exploratory factor analysis (EFA) and outcome is used to create model in AMOS for applying confirmatory factor analysis (CFA) 
analysis will be done using structural equation modeling (SEM) in AMOS. Structural equation modeling will be used to analyze the magnitude of the exogenous and endogenous variables and to identify the relationships and impact of variable.

\section{Analysis and Interpretations}

\subsection{Sample Demographics and Data Screening}

This section explored the profile of respondents through assessment of the data used. So, in this secession tactics of data screening such as descriptive statistics, treatment of missing data is discussed.

\subsection{Illustration of Respondents Profile}

Certain demographic factors of the sample under study were explored using descriptive analysis. The demographic factors such as marital status, age, education, income and $3 \mathrm{~S}$ dealers are studied in this unit. Table 4.1 represents demographics results of this research.

Results highlighted that the sample varies in terms of age group, as most of the respondents of the sample (51\%) belong to the age group of 20 to 25 followed by a relatively elder age group of 25 to 30 years (45\%). Table 4.1 highlights that majority of the respondents in the study have matric (70\%). Table 4.1 also represents the marital status of the respondents indicating highest ratio of unmarried respondents $(59 \%)$, most of the respondent getting income 11000-20000 income (55\%). Seven 3S dealers are shown in the table. The highest ratio of the respondent (27\%) belongs to Toyota Multan motors.

As in table 4.1 marital status (MS) shows among 350, and 206 respondents that is $59 \%$ were single and $41 \%$ were married. It shows that unmarried people in $3 \mathrm{~S}$ dealers of automobile manufactures more than married. This also supports that trend persons influence organization citizenship behavior are as majority in the current study was of the unmarried who perform well to achieve required OCB level. Additionally, these results show that married people have less to enhance OCB but not as bad as $41 \%$ people do. Therefore, in the recent study who are electing OCB were single more than married.

As table 4.1, shows that $51 \%$ customer fall in the age bracket of 20-25 years' youngsters and similar results were expected as in the literature it is found that innovators are mostly youngsters who perform more than old age people do. Usually itis supposed that young generation is motivated more than old aged people are and get motivation in their daily life in Pakistan, so mostly youngsters are fit with organization and job.

Similar, results have been achieved in this study that most of elicit OCB belong to the age bracket of 20-25 years. A convenience sampling technique has been employed in current study and customers having age between 20-35 years including some old age person were approached and requested to fill the questionnaire. Due to short of time and busy situation while 3S dealers' employees refused to fill the questionnaire while some accepted the request and filled it. Majority of the employees who agreed to fill the questionnaire were youngsters and most of the old age employees refused to fill it. This is the main reason that in age bracket (given above) 51\% respondents are within the age bracket of 20-25 years. During 
data collection, it was noted that most of the employees in

Table 4.1. Sample demographics

\begin{tabular}{llll}
\hline Demographics & Categories & Frequency $(n)$ & Percentage (\%) \\
\hline \multirow{3}{*}{ Marital Status } & Single & 206 & \\
& Married & 144 & 59.0 \\
Education & Matric & 245 & 41.0 \\
& Intermediate & 102 & 71.0 \\
Age & Bachelor \& Above & 3 & 29.0 \\
& $21-25$ & 178 & 01.0 \\
Income & $26-30$ & 157 & 51.0 \\
& $31 \&$ above & 15 & 45.0 \\
& $<10000$ & 21 & 04.0 \\
& $11000-20000$ & 192 & 06.0 \\
& $21000-30000$ & 118 & 55.0 \\
Total & $31000 \&$ above & 19 & 34.0 \\
\hline
\end{tabular}

$3 \mathrm{~S}$ dealers were young. It is clearly mentioned in the thesis that age of the respondents in the sample will be between 20-35 years. Furthermore, demographics table shows that respondents from all given age brackets are present in the study. Therefore, from above explanation, it can be said that this study is free from sample biasness issue.

As it was expected, youngsters are in $3 \mathrm{~S}$ dealers, so maximum are matriculate who are fit with organization and job it is the reason they are more motivated than other. Above table, clearly shown most of the respondent had metrics level education. It means matriculate employees are more fit with organization and job who perform well to achieve OCB level than Intermediate and others.

As in table, shows that most of employee have income in between 11000-20000, which shows the group of employee, are enhancing more OCB. Surprisingly 6\% employee belong to the income level less than 10000. It is observed in the literature that mostly employees are motivated and fit are getting normal salary. The 5\% customers belong to income level of greater than 30000 .

Furthermore, 3S dealers were selected from Suzuki Multan motors, Toyota Multan motors, Suzuki motors, Suzuki pioneer motors, Suzuki fort motors, Honda motors and Toyota city motors. The highest ratio of the respondent $27 \%$ belongs to Toyota Multan motors and the lowest ratio of $3 \mathrm{~S}$ dealers are Suzuki pioneer motors and Toyota city motors. As males are doing job in service and spare parts department of automobile manufactures in Multan district and mostly employees of Toyota Multan motors participated in giving response. 


\subsection{Reliability of Construct}

Prior to continue the research process, pilot study was conducted in which 75 cases were used to check the reliability of the instrument. Scale demonstrated satisfactory internal reliability and shown in the table below.

Table 4.2. Reliability of constructs

\begin{tabular}{cc}
\hline Scale & Cronbach's Alpha \\
\hline Person Organization Fit & .847 \\
Person Job Fit & .951 \\
Employee Motivation & .744 \\
Organization Citizenship Behavior & .859 \\
Organizational culture & .712 \\
\hline
\end{tabular}

\section{Measurement of normality}

It is important to check the assumption of normality before moving forward to the SEM analysis. In certain studies, it is stated that non-normality of the data does not cause issues when data size is large as (>300 or 400) (Ghasemi \& Zahediasl, 2012). As the values of skewness and kurtosis lies in between the \pm 5 refers that the data is normal.

Table 4.3. Descriptive statistics

\begin{tabular}{|c|c|c|c|c|c|c|c|c|c|}
\hline & $\mathrm{N}$ & Minimum & Maximum & Mean & Std. & \multicolumn{2}{|c|}{ Skewness } & \multicolumn{2}{|c|}{ Kurtosis } \\
\hline & Statistic & Statistic & Statistic & Statistic & Statistic & Statistic & $\begin{array}{l}\text { Std. } \\
\text { Error }\end{array}$ & Statistic & $\begin{array}{l}\text { Std. } \\
\text { Error }\end{array}$ \\
\hline Person org. fit & 350 & 1.00 & 5.00 & 2.0633 & .52390 & .539 & .130 & .332 & .260 \\
\hline Person job fit & 350 & 1.00 & 5.00 & 2,2100 & .60425 & .612 & .130 & .730 & .260 \\
\hline $\begin{array}{l}\text { Employee } \\
\text { motivation }\end{array}$ & 350 & 1.00 & 5.00 & 2.2545 & .57818 & .489 & .130 & .155 & .260 \\
\hline $\mathrm{OCB}$ & 350 & 1.00 & 5.00 & 2.3941 & .45771 & -.159 & .130 & -.493 & .260 \\
\hline Org. culture & 350 & 1.00 & 5.00 & 2,2100 & .60425 & .312 & .130 & .730 & .260 \\
\hline $\begin{array}{l}\text { Valid } \\
\text { wise) }\end{array}$ & 350 & & & & & & & & \\
\hline
\end{tabular}

\subsection{Analysis Summary}

Date and Time

Date: Tuesday, June 2, 2015

Time: 1:09:56 AM

Title

Sem: Tuesday, June 2, 2015 1:09 AM

Groups

Group number 1 (Group number 1)

Notes for Group (Group number 1)

The model is recursive. 
Sample size $=350$

Variable Summary (Group number 1)

Your model contains the following variables (Group number 1)

Observed, endogenous variables

EM

OCB

Observed, exogenous variables

POF

PJF

Unobserved, exogenous variables

e1

e2

Variable counts (Group number 1)

KMO and Bartlett's test of sphericity

KMO \& Bartlett's Test of Sphericity is a measure of sampling adequacy that is recommended to check the case to variable ratio for the analysis being conducted. In most academic and business studies.

Table 4.4. KMO and Bartlett's test of sphericity

\begin{tabular}{lccccc}
\hline KMO and Bartlett's Test & $\begin{array}{l}\text { Person } \\
\text { Organizatior Job Fit } \\
\text { Fit }\end{array}$ & $\begin{array}{l}\text { Person } \\
\text { Motivation }\end{array}$ & $\begin{array}{l}\text { Employee } \\
\text { Organization } \\
\text { Citizenship } \\
\text { Behavior }\end{array}$ & $\begin{array}{l}\text { Organizational } \\
\text { Culture }\end{array}$ \\
\hline $\begin{array}{l}\text { Kaiser-Meyer-Olkin } \\
\begin{array}{l}\text { Measure of Sampling } \\
\text { Adequacy. }\end{array}\end{array}$ & .804 & .772 & .854 & .826 & .754 \\
$\begin{array}{l}\text { Approx. Chi-Square } \\
\text { Bartlett's Test of Sphericity } \\
\text { df }\end{array}$ & 503.129 & 566.458 & 1432.345 & 2477.796 & 1343.346 \\
Sig & 15 & 15 & 66 & 190 & 76 \\
\hline
\end{tabular}

\subsection{Overall Measurement Model Fit}

During the process of model measurement 31-items have been excluded from the model to achieve a better fit, based on results achieved from EFA, $1^{\text {st }}$ order CFA. Person organization fit, person job fit and organizational culture have been treated as independent variable to check the effect on organization citizenship behavior with employee motivation being mediator. 
Table 4.5. Measurement model

\begin{tabular}{cc}
\hline & Overall measurement model \\
\cline { 2 - 2 } Fit Indices & Final $(13$-items $)$ \\
CMIN/df & 1.790 \\
GFI & .962 \\
IFI & .942 \\
TLI & .907 \\
CFI & .939 \\
\hline
\end{tabular}

\subsection{Construct validity}

Here the focus is upon the areas of divergent and convergent validity. Coefficients of both contribute towards the support or rejection of construct validity.

Table 4.6. Validities of construct

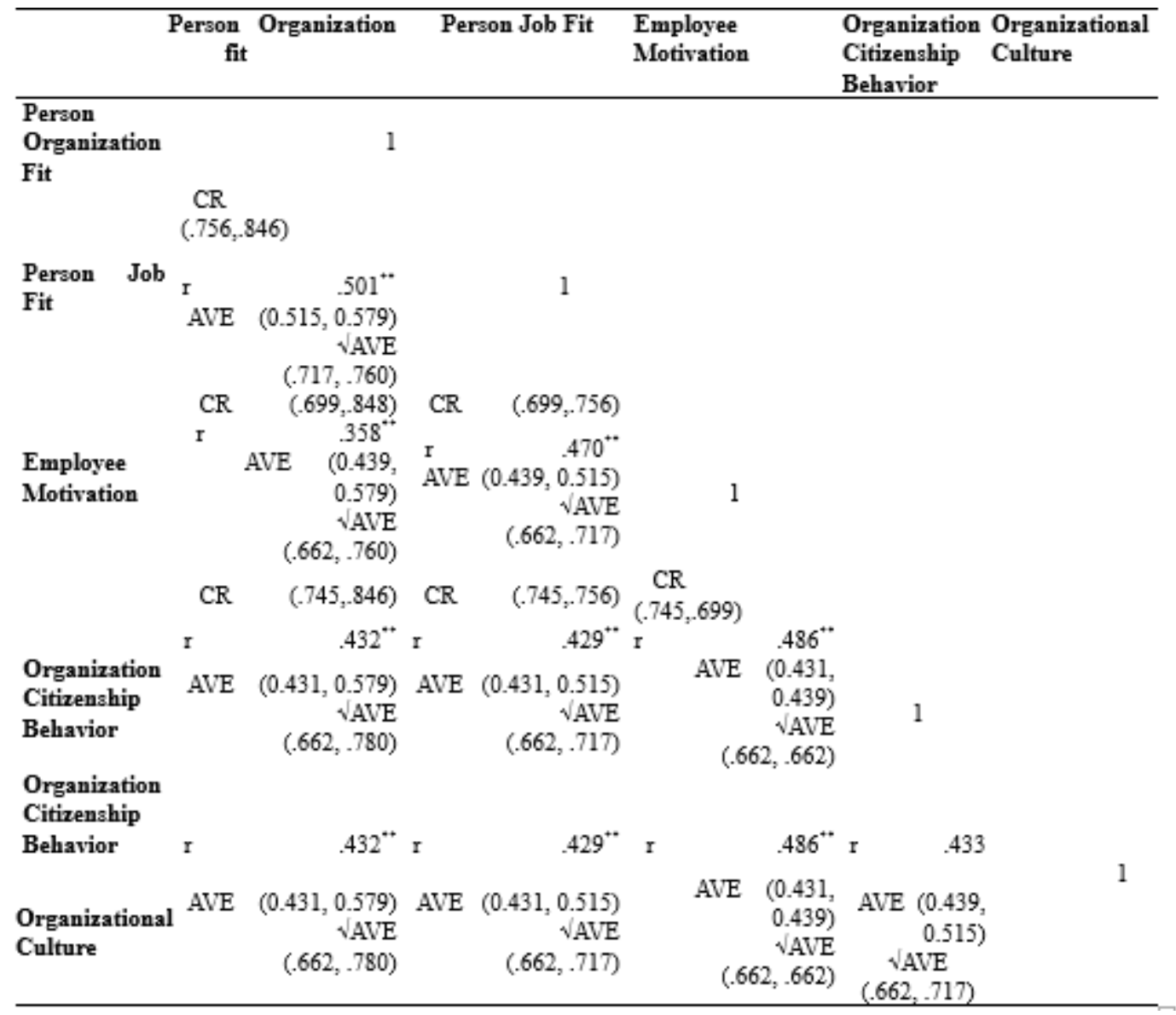

$* * \mathrm{p}<.01$ (sig. at two tail)

Pearson correlation is followed by AVE and square root of AVE

$* * \mathrm{CV}$ (Convergent Validity) $=\mathrm{AVE}>.50$ or $\mathrm{CR}>0.60$ if AVE $<0.50$ (Fornell \& Larcker, 1981).

$* * *$ DV $($ Discriminent Validity) $=$ Sq.root of AVE $>$ Correlation (Fornell \& Larcker, 1981) or $\mathrm{DV}=$ Correlation $<0.8$ (Brown, 2006). 
In above given constructs have MSV $\angle$ AVE which shows there is no issue in the divergent validity of these constructs. However, by following the rule of Brow et al., (2006) divergent validity of the constructs is acceptable even their MSV>AVE. These values clearly show divergent validity of the constructs.

\subsection{Structure Equation Model}

Structural equation modeling (SEM) includes models in which regressions among the continuous latent variables are estimated (Bollen, 1989; Browne \& Arminger, 1995; Joreskog \& Sorbom, 1979). In these models, the latent variables are continuous. Observed dependent variable, variables can be continuous, censored, binary, ordered categorical (ordinal), unordered categorical (nominal), counts, or combinations of these variables types.

Person organization fit relationship with organization citizenship behavior proved with the statistical analysis with the standardized regression of 0.236 and the significant value .002 , which is less than the threshold level and we are 99\% confident that the exogenous variable is effecting the dependent variable. And the $\mathrm{H6}$ is that organization culture has significant relationship with organization citizenship behavior this hypothesis is also accepted with the standardized regression of 0.167 and the significant value .003 as more importance is given to both. And the $\mathrm{H} 2$ hypothesis is that person job fit has significant relationship with organization citizenship behavior this hypothesis is also accepted with the standardized regression of 0.157 and the significant value .004 as more importance is given to both. Organizational culture. The effect of employee motivation and organizational citizenship behavior is positively associated with each other with the standardized regression of 0.328 and the significant value of .002 , which is significant with the organizational citizenship behavior.

\subsection{Direct and Indirect Effects}

The direct and indirect relationships between the independent, dependent variables with and without mediator are given in the table below. The results represented that both paths with and without mediator were significant. Which leads to partial and full mediation. Furthermore, other paths such as independent variables person organization fit, person job fit and organizational culture having an influence on dependent variable organization citizenship behavior are also significant along with mediating variable employee motivation. The mediator employee motivation also exhibits a significant path with dependent variable of current study. The significant path is direct and indirect path between person job fit and organization citizenship behavior with full and partial mediation and significant between person job fit and employee motivation. All other relations are also significant at $\mathrm{p}<.05$.

Regarding hypothesis 1, tAnalysis Summary

Date and Time

Date: Tuesday, June 2, 2015

Time: 1:09:56 AM 


\section{Macrothink}

Title

Sem: Tuesday, June 2, 2015 1:09 AM

Groups

Group number 1 (Group number 1)

Notes for Group (Group number 1)

The model is recursive.

Sample size $=350$

Variable Summary (Group number 1)

Your model contains the following variables (Group number 1)

Observed, endogenous variables

\section{EM}

OCB

Observed, exogenous variables

POF

PJF

Unobserved, exogenous variables

e1

e2

Variable counts (Group number 1)

here lies significant relationship between about person organization fit and organization citizenship behavior, where p-value is .002. Hence, hypothesis H1 is supported which states that person organization fit influences organization citizenship behavior. According to the results, person organization fit has positive impact on organization citizenship behavior with standardized regression weight .236 . However, the relationship is significant.

The p-value .010 and standardized regression weights is .157. PJF-OCB direct relationship leads to the conclusion that there is a significant impact of person job fit on organization citizenship behavior. Hence it accepts hypotheses H2. According to Hsu et al., (2012) the study result supports the hypothesis $\mathrm{H} 2$.

There exists a significant relation between employee motivation and organization citizenship behavior, where p-value is .002. Hence, hypothesis H3 is supported which states that employee motivation influences organization citizenship behavior, having a standardized regression weight of .328 . 
Person organization fit has significant relationship with employee motivation provides us with value of standardized regression weigh .163 and p-value .004 . The results support the hypothesis $\mathrm{H} 4$.

The p-value is 0.001 and standardized regression weights .157. PJF-EM direct relationship leads to the conclusion that there is a significant impact of person job fit on employee motivation. Hence it accepts hypotheses H5. According to Hackman (1980) and Edward (1991) the study results support the hypothesis H5.

Furthermore, Employee motivation has significant relationship between person organization fit and organization citizenship behavior provides us with value o with a p-value .002 and standardized regression weights is .338. As according to khaola and Sebotsa (2015) and Vilela et al., (2008) there exist a positive relation between person organization fit and organization citizenship behavior. Thus, the results support the Hypothesis H1a. Similarly, OC-OCB (organizational culture, organizational citizenship behavior) also has a significant relation with $\mathrm{p}<.05$ and regression weight 0.167 .

Employee motivation has significantly mediated the indirect relations between person job fit and organization citizenship behavior with standardized regression weights of .236 and p-value .001. As according to Jawad et al., (2013) there exist a positive relation between person job fit and organization citizenship behavior. So H2a is significant.

\section{Discussion and Conclusion}

The primary objective of this research was to identify the effect of two predictors, which were person organization fit, person job fit and organizational culture with a mediating role of employee motivation. The results showed that there is significant partial and full mediation between mediated variables (POF-EM-OCB), significant partial and full mediation between (PJF-EM-OCB) and significant partial and full mediation between (OC-EM-OCB). Hence, person organization fit directly effects the mediated relationship of employee motivation on organization citizenship behavior, such as when employees are motivated they perform wellbeing for the organization. Current study shows an indirect and direct significant relation of person job fit. This study shows an indirect and direct significant relation of organizational culture. While person organization fit is concerned, its relation with organization citizenship behavior is significantly proven in this study as results show a strong significant relation between these two variables. Person organization fit has both direct and indirect significant relationship with organization citizenship behavior, which shows importance of the factors. Further, in literature their relation is shown significant means previous studies observed a relationship between person organization fit, person job fit, organizational culture and citizenship behavior through mediating effect of employee motivation. However, employee motivation as observed in this study is a strong enough factor which affect person organization fit, person job fit, organizational culture and organization citizenship behavior.

Overall, the results of this study provide a strong support for the hypothesized model. The results support the mediating role of employee motivation in the relationships between P-O, P-J, OC and OCB. Utilizing Katz' (1966) categorization of employee behavior and social 
exchange theory, the results imply that the fit which an employee perceives between his/her needs and capabilities and the benefits the job/or organization offer induces the individual to become a member of the organization and perform the expected task. At this stage, it is possible that employees act in uncalculated ways and become involved in activities with an unspecific future return in which the obligation of the organization to reciprocate is not obvious. The extent of fit leads employees to commit to the organization and show higher levels of OCB. The strength of these relationships is consistent with that found in previous research in P-O fit, P-J fit and OC. In addition, Greguras and Diefendorff (2009) confirmed that individuals are attracted to organizations with similar values as this allows them to promote their commitment and desire to stay in the organization. This research studied individual perception of fit rather than actual fit and suggests that organizations should try to influence the fit perception of employees as well as create the actual fit. The causal relationship that fit might enhance employee motivation and the relationship relies mainly on theory. However, the findings of Vilela et al. (2008) indicated that organizations could profit in very tangible ways of attracting and selecting employees who fit well into the company. The organization shapes a community that influences employees in a broad way, e.g. through identity or by directing employees to behave in ways they might not under normal circumstance (King et al., 2010). The model and results show that there are partial and full mediating effects that influence the relationship among P-O fit, P-J fit, OC and OCB. This is contrary to previous research that suggest that EM does not play a considerable role in relationship $\mathrm{P}-\mathrm{O}$ and $\mathrm{OCB}$ because there is no direct relationship between EM and OCB (Huei et al., 2014). Anyhow previous studies also suggest that when, employees are motivated employees need to feel encouraged to have stronger OCB.

\subsection{Managerial Implications}

The study provides useful insights for managerial implication to be implemented in the organization. The quantitative part of SEM states its role by opposing and accepting of the hypothesis thus by providing the view which items and variables more strongly effects the OCB build and the qualitative part delivers the theoretical basis for intangible characteristics to be focused like beliefs and values. Some of the managerial implications are as follows:

Managers can use OCB as an indicator that can provide useful information on an employee's state of mind and how they perceive the organizations and whether any factors force them to make their minds to leave the organization. This research proves that person organization fit increase organization profit, when person hiring is suitable than person increases OCB level and that person are ideal for productivity. Decision-making processes, which are related to customer, must involve an active commitment of company and provide customers complete summary related to any change in product. The managerial implication determined from the research is that it can deliver a view to management to enhance a culture in organization that is transferred to gain mutual benefit.

\subsection{Limitations}

This study was conducted comprising few constructs only, possibly a number of exogenous variables may not have been considered, and they could have an influential impact on the 
dependent variable. So, new constructs can be added into the model, including supervisor support, environmental fit etc. For a clear understanding of OCB, longitudinal analysis can be performed as time can affect the results. Due to time constraints, the data was collected only from 3S dealers of automobile manufacturers in the Multan district. Because of the different socio-cultural values of the country, the study may have different findings if data is collected from a balanced mix of all major cities. A comparative analysis can deliver useful understandings.

\section{References}

Allen, T. D., \& Rush, M. C. (1998). The effects of organizational citizenship behavior on performance judgments: a field study and a laboratory experiment. Journal of applied psychology, 83(2), 247. 60. https://doi.org/10.1037/0021-9010.83.2.247

Bandura, A. (1986). The explanatory and predictive scope of self-efficacy theory. Journal of Clinical and Social Psychology, 4, 359-373. https://doi.org/10.1521/jscp.1986.4.3.359

Bateman, T. S., \& Organ, D. W. (1983). Job satisfaction and the good soldier: The relationship between affect and employee "citizenship".Academy of management Journal, 26(4), 587-595. https://doi.org/10.2307/255908

Bell, S. J., \& Menguc, B. (2002). The employee-organization relationship, organizational citizenship behaviors, and superior service quality. Journal of Retailing, 78, 131-14. https://doi.org/10.1016/S0022-4359(02)00069-6

Blau, G. (1964). Exchange and power in social life. Transaction Publishers.

Blau, P. (1964). Exchange and power in social life. Transaction Publishers.

Blau, P. M. (1964). Exchange and power in social life. Transaction Publishers.

Blau, P. M. (1964). Exchange and power in social life. Transaction Publishers.

Bollen, K. A. (1989). A new incremental fit index for general structural equation models. Sociological Methods \& Research, 17(3), 303-316. https://doi.org/10.1177/0049124189017003004

Bowen, D. E., Ledford, J. G. E., \& Nathan, B. R. (1991). Hiring for the organization, not the job. Academy of Management Perspectives, 5(4), 35-51. https://doi.org/10.5465/AME.1991.4274747

Browne, M. W., \& Arminger, G. (1995). Specification and estimation of mean-and covariance-structure models. In Handbook of statistical modeling for the social and behavioral sciences (pp. 185-249). Springer, Boston, MA. https://doi.org/10.1007/978-1-4899-1292-3_4

Cable, D. M., \& DeRue, D. S. (2002). The convergent and discriminant validity of subjective fit perceptions. Journal of Applied Psychology, 87(5), 875-884. 4. https://doi.org/10.1037/0021-9010.87.5.875 


\section{$\triangle$ Macrothink}

International Journal of Human Resource Studies

ISSN 2162-3058

2018, Vol. 8, No. 2

Cable, D. M., \& DeRue, D. S. (2002). The convergent and discriminant validity of subjective $\begin{array}{lllll}\text { fit perceptions. Journal of applied psychology, } 87(5), & 875 .\end{array}$ https://doi.org/10.1037/0021-9010.87.5.875

Cable, D. M., \& Parsons, C. K. (2001). Socialization tactics and person-organization fit. Personnel Psychology, 54(1), 1-23.

Conger, J. A., \& Kanungo, R. N. (1988). The empowerment process: Integrating theory and practice. Academy of management review, 13(3), 471-482. https://doi.org/10.5465/AMR.1988.4306983

DeNisi, A. S., Cafferty, T. P., \& Meglino, B. M. (1984). A cognitive view of the performance appraisal process: A model and research propositions. Organizational behavior and human performance, 33(3), 360-396.doi:10.1016/0030 5073(84)90029-1

Edwards, J. R. (1991). Person-job fit: A conceptual integration, literature review, and methodological critique. John Wiley \& Sons.

Elfenbein, H. A., \& O'Reilly, C. A. (2007). The effects of relational demography and person-culture fit on group process and performance, Group Organisation Management, 32(1), 109-142. https://doi.org/10.1177/1059601106286882

George, J. M., \& Bettenhausen, K. (1990). Understanding prosocial behavior, sales performance, and turnover: A group-level analysis in a service context. Journal of applied psychology, 75(6), 698. https://doi.org/10.1037/0021-9010.75.6.698

George, J. M., Jones, G. R., \& Sharbrough, W. C. (2002). Understanding and managing organizational behavior.

Greguras, G. J., \& Diefendorff, J. M. (2009). Different fits satisfy different needs: linking person-environment fit to employee commitment and performance using self-determination theory. Journal of applied psychology, 94(2), 465. https://doi.org/10.1037/a0014068

Hackman, J. R. (1980). Work redesign and motivation. Professional Psychology, 11(3), 445. https://doi.org/10.1037/0735-7028.11.3.445

Harris, K. J., Wheeler, A. R., \& Kacmar, K. M. (2009). Leader-member exchange and empowerment: Direct and interactive effects on job satisfaction, turnover intentions, and performance. The Leadership Quarterly, 20(3), 371-382. https://doi.org/10.1016/j.obhdp.2011.04.001

Hui, C., Lee, C., \& Rousseau, D. M. (2004). Psychological contract and organizational citizenship behavior in China: Investigating generalizability and instrumentality. Journal of Applied Psychology, 89(2), 311-321. https://doi.org/10.1037/0021-9010.89.2.311

Jawad, T. R., \& Abraiz. (2013). Study on Work Place Behaviour: Role of Person-Organization Fit, Person-Job Fit \& Empowerment, Evidence from Pakistan. Journal of Bussines and Management Sciences, 1(4), 47-54. http://pubs.sciepub.com/jbms/1/4/2. Diunduh 27 Maret 2015 pukul 12:26. 
Joreskog, K. G., Sorbom, D., \& Magidson, J. (1979). Advances in factor analysis and structural equation models.

Karambayya, R. (1990). Good organizational citizens do make a difference. Proceedings of the Administrative Sciences Association of Canada (pp. 110-119). Whistler, British Columbia: The Administrative Sciences of Canada.

Katz, D., \& Kahn, R. L. (1966). The Social Psychology of Organizations. Katz, D. (1964), "The motivational basis of organizational behavior", Behavioral science, 9(2), 131-146. https://doi.org/10.1002/bs.3830090206

Khaola, P. P., \& Sebotsa, T. (2015). Person-organisation fit, Organisational commitment and organisational citizenship Behaviour.

Kim, B. P., Losekoot, E., \& Milne, S. (2013). Consequences of empowerment among restaurant servers: helping behaviors and average check size, Management Decision, 1(4), 781-794. https://doi.org/10.1108/00251741311326563

King, C., \& Grace, D. (2010). Building and measuring employee-based brand equity. European Journal of Marketing, 44(7/8), 938-971. https://doi.org/10.1108/03090561011047472

King, K. A. (2016). The talent deal and journey: understanding how employees respond to talent identification over time. Employee Relations, 38(1), 94-111. https://doi.org/10.1108/ER-07-2015-0155

Koys, D. J. (2001). The effects of employee satisfaction, organizational citizenship behavior, and turnover on organizational effectiveness: A unit-level, longitudinal study. Personnel psychology, 54(1), 101-114. https://doi.org/10.1111/j.1744-6570.2001.tb00087.x

Kristof, A. L. (1996). Person-organization fit: An integrative review of its conceptualizations, measurement, and implications. Personnel Psychology, 49, 1-49. https://doi.org/10.1111/j.1744-6570.1996.tb01790.x

Kristof, B. A. L., Zimmerman, R. D., \& Johnson, E. C. (2005). Consequences of individuals' fit at work: A meta-analysis, of person-job, person-organization, person-group, and person-supervisor fit. Personnel Psychology, 58(2), 281-342. https://doi.org/10.1111/j.1744-6570.2005.00672.x

Lent, R. W., Brown, S. D., \& Hackett, G. (1994). Toward a unifying social cognitive theory of career and academic interest, choice, and performance. Journal of vocational behavior, 45(1), 79-122. https://doi.org/10.1006/jvbe.1994.1027

LePine, J. A., Erez, A., \& Johnson, D. E. (2002). The nature and dimensionality of organizational citizenship behavior: a critical review and meta-analysis. Journal of applied psychology, 87(1), 52. https://doi.org/10.1037/0021-9010.87.1.52

MacCallum, R. C., Browne, M. W., \& Sugawara, H. M. (1996). Power analysis and determination of sample size for covariance structure modeling. Psychological methods, 1(2), 
130. https://doi.org/10.1037/1082-989X.1.2.130

MacKenzie, S. B., Podsakoff, P. M., \& Ahearne, M. (1998). Some possible antecedents and consequences of in-role and extra-role salesperson performance. The Journal of Marketing, 87-98. https://doi.org/10.2307/1251745

Maddi, S. R., Harvey, R. H., Khoshaba, D. M., Lu, J. L., Persico, M., \& Brow, M. (2006). The personality construct of hardiness, III: Relationships with repression, innovativeness, authoritarianism, and performance. Journal of personality, 74(2), 575-598. https://doi.org/10.1111/j.1467-6494.2006.00385.x

Manetje, O., \& Martins, N. (2009). The relationship between organisational culture and organisational commitment. Southern African Business Review, 13(1), 87-111.

Menguc, B. (2002). The employee-organization relationship, organizational citizenship behaviors, and superior service quality. Journal of Retailing, 78, 131-14. https://doi.org/10.1016/S0022-4359(02)00069-6

Molm, L. D. (1997). Coercive power in social exchange. Cambridge University Press. https://doi.org/10.1017/CBO9780511570919

Mowday, R., Porter, L.W., \& Steers, R. M. (1982). Employee-Organisations Linkages: The Psychology of Commitment, Absenteeism, and Turnover, Academic Press, New York, NY.

Netemeyer, R. G., Boles, J. S., McKee, D. O., \& McMurrian, R. (1997). Antecedents of organizational citizenship behaviors. Journal of Marketing, 61(3), 85-98. https://doi.org/10.2307/1251791

Newton, C. J., \& Jimmieson, N. L. (2009). Subjective fit with organizational culture: an investigation of moderating effects in the work stressor-employee adjustment relationship. The International Journal of Human Resource Management, 20(8), 1770-1789. https://doi.org/10.1080/09585190903087198

O'Reilly, C. A., \& Caldwell, D. F. (1985). The impact of normative social influence and cohesiveness on task perceptions and attitudes: A social information processing approach. Journal of occupational psychology, 58(3), 193-206. https://doi.org/10.1111/j.2044-8325.1985.tb00195.x

Organ, D. W. (1988). Organizational citizenship behavior: The good soldier syndrome. Lexington Books/DC Heath and Com.

Organ, D. W. (1997). Organizational citizenship behavior: It's construct clean-up time. Human performance, 10(2), 85-97. https://doi.org/10.1207/s15327043hup1002_2

Organ, D. W., \& Near, J. P. (1983). Organizational citizenship behavior: Its nature and $\begin{array}{lllll}\text { antecedents. Journal of applied } & \text { psychology, } & 68(4), & 653 .\end{array}$ https://doi.org/10.1037/0021-9010.68.4.653

Podsakoff, N. P., Whiting, S. W., Podsakoff, P. M., \& Blume, B. D. (2009). Individual-and organizational-level consequences of organizational citizenship behaviors: A meta-analysis. 
Journal of applied Psychology, 94(1), 122. https://doi.org/10.1037/a0013079

Podsakoff, P. M., \& MacKenzie, S. B. (1997). Impact of organizational citizenship behavior on organizational performance: A review and suggestion for future research. Human performance, 10(2), 133-151. https://doi.org/10.1207/s15327043hup1002_5

Podsakoff, P. M., Ahearne, M., \& MacKenzie, S. B. (1997). Organizational citizenship behavior and the quantity and quality of work group performance. Journal of Applied Psychology, 82, 262-270. https://doi.org/10.1037/0021-9010.82.2.262

Podsakoff, P. M., Mackenzie, S. B., Moorman, R. H., \& Fetter, R. (1990). Transformational leader behavior and their effects on followers' trust in leader, satisfaction and organizational citizenship behaviors, Leadership Quarterly, 1(2), $107-\quad 142$. https://doi.org/10.1016/1048-9843(90)90009-7

Rashid, Z, A., Sambasivan, M., \& Abdul, R. A. (2004). The influence of organizational culture on attitudes toward organizational change. Leadership \& organization development Journal, 25(2), 161-179. https://doi.org/10.1108/01437730410521831

Rousseau, D. M. (1990). Normative beliefs in fund-raising organizations: Linking culture to organizational performance and individual responses. Group \& Organization Studies, 15(4), 448-460. https://doi.org/10.1177/105960119001500408

Sekiguchi, T., \& Huber, V. L. (2011). The use of person-organisation fit and person-job fit information in making selection decisions, Organisational Behavior \& Human Decision Processes, 116(2), 203-216. https://doi.org/10.1016/j.obhdp.2011.04.001

Tylor, E. B. (1874). Primitive culture: Researches into the development of mythology, philosophy, religion, language, art and customs (Vol. 1). H. Holt.

Van Dyne, L., Graham, J. W., \& Dienesch, R. M. (1994). Organizational citizenship behavior: Construct redefinition, measurement, and validation. Academy of management Journal, 37(4), 765-802. https://doi.org/10.2307/256600

Vilela, B. B., González, J. A. V., \& Ferrín, P. F. (2008). Person-organization fit, OCB and performance appraisal: Evidence from matched supervisor-salesperson data set in a Spanish context. Industrial Marketing Management, 37(8), 1005-1019. https://doi.org/10.1016/j.indmarman.2007.11.004

Vilela, B. B., González, J. A. V., \& Ferrín, P. F. (2008). Person-organization fit, OCB and performance appraisal: Evidence from matched supervisor-salesperson data set in a Spanish context. Industrial Marketing Management, 37(8), 1005-1019. https://doi.org/10.1016/j.indmarman.2007.11.004

Vogel, R. M., \& Feldman, D. C. (2009). Integrating the levels of person-environment fit: The roles of vocational fit and group fit. Journal of vocational behavior, 75(1), 68-81. https://doi.org/10.1016/j.jvb.2009.03.007

Walz, S. M., \& Niehoff, B. P. (1996, August). Organizational citizenship behaviors and their 


\section{Macrothink}

International Journal of Human Resource Studies

ISSN 2162-3058 2018, Vol. 8, No. 2

effect on organizational effectiveness in limited-menu restaurants. In Academy of management proceedings (Vol. 1996, No. 1, pp. 307-311). Briarcliff Manor, NY 10510: Academy of Management. https://doi.org/10.5465/AMBPP.1996.4980770

Yuan, B. J., Hsu, W. L., Shieh, J. H., \& Li, K. P. (2012). Increasing emotional intelligence of employees: Evidence from research and development teams in Taiwan. Social Behavior and Personality: an international journal, 40(10), 1713-1724. https://doi.org/10.2224/sbp.2012.40.10.1713

\section{Copyright Disclaimer}

Copyright for this article is retained by the author(s), with first publication rights granted to the journal.

This is an open-access article distributed under the terms and conditions of the Creative Commons Attribution license (http://creativecommons.org/licenses/by/4.0/). 